\title{
POLITIK HUKUM PERADILAN TATA USAHA NEGARA \\ DI INDONESIA
}

\author{
Oleh : \\ Wahyu Beny Mukti Setiyawan, $\mathrm{SH}, \mathrm{MH}$ \\ Prijo Dwi Atmanto, S.Pd, SH, M.Si \\ Hana Hanifia Yusrima Latifa Hanum \\ Fakultas Hukum Universitas Islam Batik Surakarta \\ Email : muktibeny@gmail.com,
}

\begin{abstract}
Abstraksi
Politik hukum hadir di titik perjumpaan antara realisme hidup dengan tuntutan idealisme. Politik hukum menyangkut sebuah cita-cita atau harapan, maka terdapat visi hukum yang ditetapkan terlebih dahulu yang kemudian bentuk dan isi hukum dibangun untuk mewujudkan visi tersebut. Urgensi keberadaan peradilan administrasi dalam mewujudkan Negara hukum mendorong pemerintah untuk membentuk sistem hukum dibidang peradilan administrasi, yakni melalui pembentukan Undang-Undang Nomor 5 Tahun 1986 Tentang Peradilan Tata Usaha Negara, yang merupakan fondasi bagi pembentukan Peradilan Tata Usaha Negara di Indonesia. Pada penjelasan Undang-Undang Nomor 5 Tahun 1986 disebutkan bahwa Peradilan Tata Usaha Negara diadakan dalam rangka memberikan perlindungan kepada rakyat percari keadilan, yang merasa dirinya dirugikan akibat suatu Keputusan Tata Usaha Negara. Secara prinsip, suatu negara diharapkan dapat memberikan perlindungan terhadap hak-hak asasi manusia warga negaranya.
\end{abstract}

Kata kunci : Politik Hukum, Peradilan Tata Usaha Negara, Indonesia. 


\title{
LAW POLITICS OF STATE ADMINISTRATION COURT IN INDONESIA
}

\author{
Wahyu Beny Mukti Setiyawan, SH, MH \\ Prijo Dwi Atmanto, S.Pd, SH, M.Si \\ Hana Hanifia Yusrima Latifa Hanum \\ Faculty of Law, Surakarta Islamic Batik University \\ Email: muktibeny@gmail.com,
}

\begin{abstract}
Law politics is present at the encounter point between living realism and the demands of idealism. Law politics concerns an ideal or hope, then there is legal vision that is set in advance, then the form and content of the law are built to realize that vision. The urgency of the existence of administrative justice in realizing the rule of law encourages the government to establish a legal system in the field of administrative justice, namely through the establishment of Law Number 5 of 1986 concerning State Administration Courts, which is the foundation for the establishment of a State Administration Court in Indonesia. In the explanation of Law Number 5 of 1986 it was stated that the State Administration Court was held in order to provide protection to the people seeking justice, who felt themselves to be harmed by a State Administrative Decision. In principle, a country is expected to provide protection for its citizens' human rights.
\end{abstract}

Keywords: Politics of Law, State Administration Court, Indonesia. 


\section{A. PENDAHULUAN}

Negara Indonesia adalah negara yang berdasarkan atas hukum (rechtsstaat), tidak berdasarkan atas kekuasaan belaka (machtsstaat). Demikian dinyatakan secara tegas dalam Pasal 1 ayat (3) Undang-Undang Dasar Negara Republik Indonesia Tahun 1945. Secara embrionik, gagasan negara hukum telah dikemukakan oleh Plato, ketika ia mengintroduksi konsep nomoi. Dalam konsep nomoi, Plato mengemukakan bahwa penyelenggaraan negara yang baik adalah yang didasarkan pada pengaturan hukum yang baik (Tahir Azhary, 1992 : 66).

Sebagai negara hukum, Indonesia menerima hukum sebagai ideologi untuk menciptakan ketertiban, keamanan, keadilan serta kesejahteraan bagi warga negaranya. Konsekuensi dari itu semua adalah bahwa hukum mengikat setiap tindakan yang dilakukan oleh warga negara Indonesia. Disamping itu pula di Negara Indonesia terdapat atribut khusus yaitu Pancasila. Hal ini mengandung pengertian bahwa Pancasila sebagai Rule of Law bukan semata-mata sebagai peraturan yang diberlakukan bagi masyarakat Indonesia. Otje Salman juga berkomentar dalam hal ini bahwa menempatkan sistem dalam idealisme tertentu yang bersifat final, dinamis dan selalu mencari tujuan-tujuan ideal berlandaskan ideologi Pancasila (R. Otje Salman Soemadiningrat, 2002 : 139).

Undang-Undang Dasar Negara Republik Indonesia Tahun 1945 sebagai dasar konstitusi Negara Indonesia telah menyebutkan secara eksplisit bentuk Pemerintahan Indonesia sebagaimana tertuang dalam Pasal 1 ayat (3) UUD NRI Tahun 1945 bahwa "Negara Indonesia adalah Negara Hukum". Dalam konsep Negara Hukum (rechsstaat) itu, diidealkan bahwa yang harus dijadikan panglima dalam dinamika kehidupan kenegaraan adalah Hukum, bukan didasarkan pada kekuasaan (machsstaat). Terkait dengan konsep suatu Negara Hukum, F.J. Stahl merumuskan unsur-unsur rechtsstaat, yaitu adanya perlindungan terhadap hak-hak asasi manusia, pemisahan atau pembagian kekuasaan Negara untuk menjamin hak-hak asasi manusia tersebut, Pemerintah berdasarkan peraturan serta adanya Peradilan Administrasi (S.F. Marbun, 2011 : 9).

Pada dasarnya konsep hukum tidak akan pernah lepas dari tujuan untuk memperoleh keadilan, karena salah satu tujuan hukum itu adalah untuk mewujudkan keadilan bagi seluruh rakyat. Keadilan itu sendiri merupakan sesuatu yang abstrak yang dimana manusia sulit untuk mendapatkan gambaran yang pasti akan makna dan arti dari keadilan itu sendiri. Ketika kita membicarakan keadilan, sebenarnya kita harus merefleksikan bahwa kita hidup di dunia ini tidak sendiri sehingga kita dituntut untuk tidak mengabaikan tanggung jawab kepada yang lain. Masalah keadilan tidak hanya cukup dapat dicapai dengan pengetahuan manusia, karena keadilan merupakan cita-cita yang irasional. 
Tiap bangsa dan negara memiliki konsep hukum yang berbeda antara yang satu dengan yang lain. Walaupun konsep yang dianut berbeda, akan tetapi hukum mempunyai tujuan yang sama yaitu tujuan ideal dari hukum itu sendiri. Hukum mempunyai visi dan misi yang dikandungnya. Visi hukum ditetapkan terlebih dahulu karena dengan visi tersebut maka akan terbentuk rancangan dari bentuk dan isi hukum itu sendiri yang akan diwujudkan nantinya. Visi hukum merupakan titik tolak dari politik hukum, karena berbicara mengenai politik hukum tidak lepas dari cita-cita atau harapan sehingga harus ada visi terlebih dahulu.

Politik hukum itu perlu, karena hukum itu perlu. Hukum diperlukan untuk menata keadaan agar lebih baik. Itulah idealisme di balik kehadiran hukum dalam komunitas manusia sejak awal. Karena itu, politik hukum hadir, di titik perjumpaan antara realisme hidup dengan tuntutan idealisme. la mengoreksi keadaan yang "kurang ideal" dan serentak menghadirkan "yang seharusnya". Sebab bila "yang ada" itu sudah baik, maka memang politik hukum tidak lagi diperlukan (Bernard L. Tanya, 2011: 13).

Dalam pembuatan perundangundangan, politik hukum memiliki peranan yang sangat penting. Pertama, sebagai alasan mengapa diperlukan pembentukan suatu peraturan perundang-undangan. Kedua, untuk menentukan apa yang hendak diterjemahkan ke dalam kalimat hukum dan menjadi perumusan Pasal. Dua hal ini penting karena keberadaan peraturan perundang-undangan dan perumusan Pasal merupakan jembatan antara politik hukum tersebut dalam tahap implementasi peraturan perundang-undangan (Abdul Latif dan Hasbi Ali, 2011 : 19).

Peradilan Administrasi sebagai salah satu unsur dalam rechsstaat ditujukan untuk memberikan perlindungan Hukum terhadap warga Negara atas tindakan Pemerintah dalam lapangan Administrasi Negara. Sebagaimana dikemukakan Anna Erliyana mengutip W.R. Wade \& C.F. Forsyth menegaskan tujuan utama dari Hukum Administrasi : the primary purpose of administrative law, therefore, is to keep the powers of government within their legal bounds, so as to protect the citizen against their abuse. Sedangkan menurut Mirlinda Batalli, administrative procedures are mechanisms for interaction between public authorities and citizens (http://www.epracticejournal.eu.

European Journal of ePractice). Dengan adanya Hukum Administrasi, maka tindakan administratif Pemerintah terhadap rakyat lebih terarah. Sedangkan Hukum Acara Administrasi sebagai mekanisme interaksi antara pemerintah dan rakyat, apabila terdapat permasalahan diantara keduanya.

Dipihak lain pihak, Peradilan Administrasi juga akan memberikan perlindungan Hukum yang sama kepada pejabat Administrasi Negara yang bertindak benar dan sesuai dengan Hukum (S.F. Marbun, 2011 : 10). Dengan demikian dengan hadirnya Peradilan Administrasi dapat memberikan 
perlindungan Hukum baik kepada warga Negara maupun pejabat terhadap tindakan Administratif Pemerintah.

Urgensi keberadaan Peradilan Administrasi dalam mewujudkan Negara Hukum mendorong Pemerintah untuk membentuk sistem Hukum dibidang Peradilan Administrasi yakni melalui pembentukan Undang-Undang Nomor 5 Tahun 1986 tentang Peradilan Tata Usaha Negara, yang merupakan fondasi bagi pembentukan Peradilan Tata Usaha Negara di Indonesia. Pada penjelasan UndangUndang Nomor 5 Tahun 1986 disebutkan bahwa Peradilan Tata Usaha Negara diadakan dalam rangka memberikan perlindungan kepada rakyat percari keadilan, yang merasa dirinya dirugikan akibat suatu Keputusan Tata Usaha Negara.

Terdapat fakta empiris bahwa putusan Pengadilan Tata Usaha Negara masih sebatas "macan kertas", hal ini ditunjukkan oleh disertasi Supandi yang menemukan bahwa sebagian besar pejabat di Sumatera Utara, sekitar 71,41\%, tidak mematuhi Putusan PTUN Medan. Pada tahun 2004, DR. Supandi meneliti 180 putusan PTUN Medan (dari 2000 putusan sejak periode 1991-2003) yang memiliki kekuatan hukum tetap dan nilai eksekusi. Dari jumlah tersebut hanya sekitar 20,59 \% putusan yang dilaksanakan oleh pejabat yang

Tergugat

(http://Kompas.com/kompas-

cetak/061/13/politikhukum/23595

37.htm). Bahwa pada kenyataannya keberadaan Peradilan TUN belum dapat memberikan jaminan perlindungan bagi rakyat yang mencari keadilan. Sehingga diperlukan perbaikan dalam sistem Peradilan TUN di Indonesia.

Reformasi terhadap sistem Peradilan TUN di Indonesia ditandai dengan perubahan Undang-Undang Nomor 5 Tahun 1986 tentang PTUN. Perubahan pertama dilakukan melalui penetapan Undang-Undang Nomor 9 Tahun 2004 tentang Perubahan atas Undang-Undang Nomor 5 Tahun 1986 tentang PTUN. Selanjutnya melalui penetapan Undang-Undang Nomor 51 Tahun 2009 tentang Perubahan Kedua atas UndangUndang Nomor 5 Tahun 1986 tentang PTUN. Perubahan terhadap Undang-Undang Nomor 5 Tahun 1986 tentang PTUN pada prinsipnya merupakan akibat dari amandemen UndangUndang Dasar 1945. Perubahan dimaksud dalam rangka memperkuat prinsip kekuasaan kehakiman yang merdeka dan bebas dari pengaruh kekuasaan lainnya dalam menyelenggarakan peradilan guna menegakkan hukum dan keadilan. Sehubungan dengan latar belakang yang telah diuraikan sebagaimana diatas, maka penulis bermaksud mengkaji bagaimanakah Politik Hukum Peradilan Tata Usaha Negara di Indonesia.

\section{B. METODOLOGI PENELITIAN}

\section{Jenis Penelitian}

Jenis penelitian ini adalah penelitian hukum normatif atau doktrinal. Hutchinson sebagaimana dikutip Peter Mahmud Marzuki mendefinisikan penelitian hukum doktrinal sebagai berikut, "Doctrinal Reseach : Reseach 
wich provides a systematic exposition of rules governing a particular legal category, analyses the relationship between rules, explain areas of difficulty and perhaps, predict future development (Terjemahan bebas : Penelitian Doktrinal : Penelitian yang memberikan penjelasan sistematis aturan yang mengatur suatu kategori hukum tertentu, menganalisis hubungan antara peraturan, menjelaskan daerah kesulitan dan mungkin, memprediksi pembangunan masa depan)" (Peter Mahmud Marzuki, 2010 : 32).

2. Jenis dan Sumber Bahan Hukum

Dalam penelitian hukum tidak mengenal adanya data, yang ada dalam penelitian hukum adalah bahan hukum. Bahan hukum terdiri dari bahan hukum primer, bahan hukum sekunder dan bahan hukum tersier. Bahan hukum primer yakni bahan hukum yang terdiri atas peraturan perundang-undangan berdasarkan hierarkinya. Bahan hukum sekunder adalah bahan hukum yang terdiri atas bukubuku teks (textbooks) yang ditulis oleh para ahli hukum yang berpengaruh (de herseende leer), jurnal-jurnal hukum, pendapat para sarjana, kasus-kasus hukum, yurisprudensi, dan hasil-hasil simposium mutakhir yang berkaitan dengan topik penelitian. Bahan hukum tersier adalah bahan hukum yang memberikan petunjuk atau penjelasan terhadap bahan hukum primer dan bahan hukum sekunder, seperti kamus hukum, encyclopedia, dan lain- lain (Johnny Ibrahim, 2006 : 295-296).

3. Teknik Pengumpulan Bahan Hukum

Teknik pengumpulan bahan hukum dalam penelitian ini adalah menggunakan teknik studi pustaka (collecting by library). Pengumpulan bahan hukum primer, bahan hukum sekunder dan bahan hukum tersier diinventarisasi dan diklasiikasi dengan menyesuaikan masalah yang dibahas. Bahan hukum yang berhubungan dengan masalah yang dibahas dipaparkan, disistematisasi, kemudian dianalisis untuk menginterpretasikan hukum yang berlaku (Johnny Ibrahim, 2006 : 296).

4. Teknik Analisis Bahan Hukum

Teknik analisis bahan hukum yang digunakan dalam penelitian hukum ini adalah dengan logika deduktif. Dalam hal ini, sumber penelitian yang diperoleh dalam penelitian ini dengan melakukan inventarisasi sekaligus mengkaji dari penelitian studi kepustakaan, aturan perundang-undangan beserta dokumen-dokumen yang dapat membantu menafsirkan norma terkait, kemudian sumber penelitian tersebut diolah dan dianalisis untuk menjawab permasalahan yang diteliti. Tahap akhir adalah menarik kesimpulan dari sumber penelitian yang diolah. Menurut Philipus M. Hadjon sebagaimana dikutip oleh Peter Mahmud Marzuki, metode deduksi sebagaimana silogisme yang diajarkan oleh Aristoteles penggunaan metode deduksi berpangkan dari pengajuan premis mayor (pernyataan 
bersifat umum). Kemudian diajukan premis minor (bersifat khusus). Dari kedua premis itu kemudian ditarik suatu kesimpulan atau conclusion (Peter Mahmud Marzuki, 2010 : 47). Di dalam logika silogistik untuk penalaran hukum yang bersifat premis mayor adalah aturan hukum sedangkan premis minornya adalah fakta hukum. Sedangkan menurut Johnny Ibrahim, mengutip pendapat Bernand Arief Shiharta, logika deduktif merupakan suatu teknik untuk menarik kesimpulan dari hal yang bersifat umum menjadi khusus yang bersifat individual (Johnny lbrahim, 2006 : 249).

\section{PEMBAHASAN}

Keberadaan Peradilan Tata Usaha Negara di Indonesia dimulai dengan lahirnya UndangUndang Nomor 5 tahun 1986 tentang Peradilan Tata Usaha Negara (untuk selanjutnya akan disebut sebagai Peradilan TUN). Dalam dinamika ketatanegaraan yang terus mengalami perkembangan, terutama pasca amandemen Undang-Undang Dasar Negara Republik Indonesia Tahun 1945, membawa perubahan penting terhadap penyelenggaraan kekuasaan kehakiman.

Sejalan dengan pendapat Lon Fuller dalam Principles Of Legality bahwa "Suatu sistem tidak boleh mengandung peraturan-peraturan yang bertentangan satu sama lainnya", maka penetapan UndangUndang Nomor 4 Tahun 2004 tentang Kekuasaan Kehakiman (Undang-Undang Nomor 48 Tahun 2009) membawa konsekuensi pada UndangUndang Nomor 5 tahun 1986 tentang Peradilan Tata Usaha Negara. Mengingat Kekuasaan Kehakiman sebagaimana diatur dalam Undang-Undang Dasar Negara Republik Indonesia Tahun 1945 meliputi Peradilan Umum, Peradilan Agama, Peradilan Militer dan Peradilan Administrasi dibawah satu atap, yaitu Mahkamah Agung. Sehingga diperlukan sinkronisasi terhadap sistem Peradilan termasuk Peradilan TUN. Oleh karenanya ditetapkanlah Undang-Undang Nomor 9 tahun 2004 tentang Perubahan Atas Undang-Undang Nomor 5 tahun 1986 tentang Peradilan TUN.

Perubahan prinsip yang terdapat dalam Undang-Undang Nomor 9 tahun 2004, adalah dihapusnya dualisme dalam kekuasaan kehakiman, menjadi satu atap di bawah kekuasaan Mahkamah Agung. Perubahan tersebut dalam rangka penerapan asas peradilan netral dalam sistem Peradilan Tata Usaha Negara di Indonesia. Selain itu perubahan dalam Undang-Undang Nomor 9 tahun 2004 tentang Perubahan atas Undang-Undang Nomor 5 tahun 1986 tentang Peradilan TUN sebagaimana disebutkan dalam Penjelasan Undang-Undang tersebut, antara lain syarat untuk menjadi Hakim dalam pengadilan di lingkungan Peradilan TUN, batas umur pengangkatan dan pemberhentian Hakim, tata cara pengangkatan dan pemberhentian Hakim, penghapusan ketentuan hukum acara yang mengatur masuknya pihak ketiga dalam suatu sengketa dan adanya sanksi terhadap pejabat yang tidak 
$\begin{array}{lr}\text { melaksanakan } & \text { putusan } \\ \text { pengadilan } & \text { telah }\end{array}$

mempunyai kekuatan hukum tetap.

Pada tahun 2009 dilakukan perubahan kedua atas UndangUndang Nomor 8 Tahun 1986, yaitu melalui penetapan UndangUndang Nomor 51 Tahun 2009 tentang Perubahan Kedua atas Undang-Undang Nomor 5 Tahun 1986 tentang Peradilan TUN. Perubahan Kedua terhadap Undang-Undang Nomor 5 Tahun 1986 tentang Peradilan TUN pada dasarnya untuk mewujudkan penyelenggaraan Kekuasaan Kehakiman yang merdeka dan peradilan yang bersih serta berwibawa, yang dilakukan melalui penataan sistem peradilan yang terpadu (integrated justice system) (Undang-Undang Nomor 51 Tahun 2009).

Beberapa perubahan penting mengenai peradilan TUN sebagaimana diatur dalam Undang-Undang Nomor 9 Tahun 2004 dan Undang-Undang Nomor 51 Tahun 2009tentang Perubahan Kedua atas UndangUndang Nomor 5 Tahun 1986 tentang Peradilan TUN akan dibahas lebih lanjut pada uraian dibawah ini :

1. Menghapus dualisme dalam kekuasaan kehakiman, menjadi satu atap di bawah kekuasaan Mahkamah Agung

Salah satu perubahan prinsip pada Undang-Undang Nomor 9 Tahun 2004, adalah mengenai penyelenggaraan kekuasaan kehakiman. Perubahan tersebut ditujukan sebagai usaha memperkuat prinsip kekuasaan kehakiman yang merdeka dan bebas dari pengaruh kekuasaan lainnya untuk menyelenggarakan peradilan guna menegakkan hukum dan keadilan. Sebagai salah satu unsur rechtsstaat sebagaimana dirumuskan oleh F.J. Stahl adalah pemisahan atau pembagian kekuasaan untuk menjamin hak-hak asasi manusia. Pemisahan atau pembagian kekuasaan tersebut meliputi pemisahan kekuasaan eksekutif, legislatif dan yudikatif. Maka untuk menjaga kemerdekaan dan kebebasan lembaga yudikatif dalam menjalankan fungsi dan perannya, pemisahan diri dari kekuasaan eksekutif merupakan suatu hal yang prinsip.

Pembinaan organisasi, administrasi dan keuangan pengadilan oleh Departemen Kehakiman dianggap tidak lagi sejalan dengan jiwa konstitusi. Pembinaan teknis maupun organisasi dan keuangan seyogyanya dilakukan dalam satu atap, yaitu oleh Mahkamah Agung. Maka melalui Undang-Undang Nomor 9 Tahun 2004 dilakukan penghapusan dualisme dalam kekuasaan kehakiman, menjadi satu atap saja, yaitu berada di bawah satu atap Mahkamah Agung saja.

Sebagaimana disebutkan pada Pasal 7 Undang-Undang Nomor 9 tahun 2004 bahwa, "Pembinaan teknis peradilan, organisasi, administrasi, dan finansial Pengadilan dilakukan oleh Mahkamah Agung". Ketentuan dalam pasal 7 Undang-Undang Nomor 9 Tahun 2004 tersebut mengakhiri dualisme 
penyelenggaran kekuasaan

kehakiman, yang semula dilakukan oleh Menteri

Kehakiman dan Mahkamah

Agung. Ketentuan tersebut tentu telah sejalan dengan asas peradilan netral. Tugas pengawasan maupun pengangkatan dan pemberhentian hakim yang semula menjadi kewenangan Menteri Kehakiman, beralih menjadi tugas Mahkamah Agung. Dengan demikian diharapkan dapat mewujudkan Peradilan TUN yang merdeka dan bebas sebagaimana diamanatkan oleh UndangUndang Dasar Negara Republik Indonesia Tahun 1945.

2. Pengangkatan

dan

\section{Pemberhentian Hakim}

a. Memperketat syarat untuk menjadi Hakim di lingkungan Peradilan TUN Persyaratan untuk dapat menjadi Hakim Pengadilan TUN diatur didalam Pasal 14 ayat (1). Persyaratan untuk menjadi Hakim di lingkungan Peradilan TUN semakin diperketat. Pada Pasal 14 ayat (1) Undang-Undang Nomor 51 Tahun 2009 disebutkan bahwa untuk dapat diangkat sebagai Hakim Pengadilan Tata Usaha Negara harus Sarjana Hukum dan lulus pendidikan Hakim. Hal tersebut berbeda dengan ketentuan Undang-Undang sebelumnya, yang tidak mensyaratkan secara mutlak kompetensi pendidikan calon Hakim. Diharapkan dengan kompetensi pendidikan
Hakim yang berasal dari Fakultas Hukum, nantinya akan dapat memiliki kapabilitas di bidang Hukum, mengingat tugas Hakim TUN relatif lebih berat. Dalam Peradilan TUN dikenal asas Hakim aktif, dimana Hakim diserahi tugas untuk menemukan kebenaran materiil terhadap sengketa yang diperiksanya. Sehingga penguasaan Hakim di bidang Hukum merupakan suatu hal penting.

Selain persyaratan kompentensi pendidikan, hal penting lain yang disyaratkan oleh UndangUndang Nomor 51 Tahun 2009 bahwa tidak pernah dijatuhi pidana penjara karena melakukan kejahatan berdasarkan putusan Pengadilan yang telah memperoleh kekuatan Hukum tetap. Selain kompetensi di bidang Hukum, seorang calon Hakim juga harus memiliki rekan jejak yang baik. Dengan semakin ketatnya persyaratan dalam pengangkatan Hakim di lingkungan Peradilan TUN di harapkan dapat menghasilkan Hakim-Hakim yang kompeten sehingga dapat memberikan keadilan bagi rakyat yang bersengketa di PTUN.

b. Pemberhentian Hakim

Selain pembaharuan pengaturan mengenai pengangkatan Hakim, dalam Undang-Undang Nomor 9 Tahun 2004 dan 
Undang-Undang Nomor 51 Tahun 2009 juga dilakukan pembenahan mengenai pemberhentian Hakim di lingkungan Peradilan TUN. Beberapa perubahan mengenai pemberhentian Hakim di lingkungan TUN antara lain :

1) Perubahan usia pensiun bagi Hakim;

2) Perubahan alasan pemberhentian tidak dengan hormat Hakim semakin diperjelas;

3) Pemberhentian Ketua atau Wakil Ketua Pengadilan dari jabatannya karena atas permintaan sendiri secara tertulis tidak dengan sendirinya diberhentikan sebagai Hakim (Pasal 21 Undang-Undang Nomor 51 Tahun 2009). Hal tersebut berbeda dengan ketentuan dalam Undang-Undang Nomor 5 Tahun 1986 bahwa seorang Hakim yang diberhentikan dari jabatannya tidak dengan sendirinya diberhentikan sebagai pegawai negeri;

4) Ketua, Wakil Ketua, dan Hakim Pengadilan jabatannya oleh Ketua Mahkamah Agung (Pasal 22 ayat (1)). Sedangkan dalam Undang-Undang Nomor 5 Tahun 1986, pemberhentian sementara dilakukan oleh Presiden selaku Kepala Negara atas usul Menteri Kehakiman berdasarkan persetujuan Ketua Mahkamah Agung. Hal tersebut tentu saja dapat mempengaruhi kemerdekaan dan kebebasan Hakim.

3. Pengawasan Terhadap Hakim di Peradilan TUN lingkungan

Terdapat perubahan dalam pengawasan terhadap Hakim. Semula pengawasan terhadap Hakim yang berada di lingkungan Peradilan TUN dilaksanakan oleh Menteri Kehakiman sebagaimana diatur dalam Pasal 13 ayat (1), "Pembinaan dan pengawasan umum terhadap Hakim sebagai pegawai negeri, dilakukan oleh Menteri Kehakiman". Pengawasan Hakim oleh Menteri Kehakiman yang merupakan bagian dari Kekuasaan Eksekutif, tentu saja bertentangan dengan asas peradilan netral karena dapat mengancam kebebasan Hakim sebagai penyelenggara kekuasaan yudikatif. Berdasarkan hal tersebut, maka dalam Undang-Undang Nomor 9 Tahun 2004 diadakan perubahan dalam hal pembinaan terhadap Hakim di lingkungan Peradilan TUN.

Pada Pasal 13 ayat (1) Undang-Undang Nomor 9 Tahun 2004 disebutkan bahwa, "Pembinaan dan pengawasan umum terhadap Hakim dilakukan oleh Mahkamah Agung". Dalam pasal tersebut, Hakim tidak sekedar diawasi sebagai pegawai negeri, akan tetapi kapasitas sepenuhnya sebagai Hakim. Pengawasan tersebut dilakukan oleh Ketua 
Mahkamah Agung, sebagai pemegang kekuasaan yudikatif yang tertinggi. Hal tersebut tentu saja telah sejalan dengan amanat konstitusi, dalam rangka membentuk peradilan yang bebas dan merdeka.

Ketentuan mengenai pengawasan terhadap Hakim di Lingkungan Peradilan TUN kembali mengalami perubahan pada Undang-Undang Nomor 51 Tahun 2009. Pada UndangUndang Nomor 51 Tahun 2009, terdapat tambahan pasal baru yaitu Pasal $13 \mathrm{~A}$, yang menyebutkan bahwa pengawasan internal atas tingkah laku hakim dilakukan oleh Mahkamah Agung. Selain Pengawasan sebagaimana dimaksud pada ayat (1), untuk menjaga dan menegakkan kehormatan, keluhuran, martabat serta perilaku hakim, pengawasan eksternal atas perilaku hakim dilakukan oleh Komisi Yudisial.

Ketentuan dalam Pasal 13 A Undang-Undang Nomor 51 Tahun 2009 memperbaiki pengaturan mengenai pengawasan terhadap Hakim. Pengawasan dibagi menjadi pengawasan internal dan pengawasan eksternal. Pengawasan internal dilakukan oleh secara komprehensif Mahkamah Agung (tidak lagi menyebut jabatan "Ketua Mahkamah Agung"). Sedangkan pengawasan eksternal dilakukan oleh Komisi Yudisial. Hal tersebut sesuai dengan tugas Komisi Yudisial sebagaimana diatur pada Pasal 20 Undang-Undang Nomor 22 Tahun 2004 tentang
Komisi Yudial, bahwa "Dalam melaksanakan wewenang sebagaimana dimaksud dalam Pasal 13 huruf B Komisi Yudisial mempunyai tugas "melakukan pengawasan terhadap perilaku Hakim dalam rangka menegakkan kehormatan dan keluhuran martabat serta menjaga perilaku Hakim".

4. Alasan Pengajuan Gugatan

Pada Pasal 53 ayat (1) Undang-Undang Nomor 9 tahun 2004 disebutkan bahwa, "Orang atau badan Hukum perdata yang merasa kepentingannya dirugikan oleh suatu Keputusan Tata Usaha Negara dapat mengajukan gugatan tertulis kepada Pengadilan yang berwenang yang berisi tuntutan agar Keputusan Tata Usaha Negara yang disengketakan itu dinyatakan batal atau tidak sah, dengan atau tanpa disertai tuntutan ganti rugi dan/atau direhabilitasi". Sedangkan dasar pengajuan gugatan diatur pada Pasal 53 ayat (2), dimana terdapat perbedaan yang cukup mendasar dalam UndangUndang Nomor 5 Tahun 1986 dan Undang-Undang Nomor 9 Tahun 2004.

Menurut ketentuan UndangUndang Nomor 5 Tahun 1986, dasar atau alasan diajukannya gugatan terhadap suatu keputusan yang dikeluarkan oleh badan atau pejabat TUN, karena keputusan TUN tersebut bertentangan dengan Peraturan Perundangundangan yang berlaku, baik bersifat prosedural atau formal dan material atau subtansial, maupun karena dukeluarkan 
oleh Badan atau Pejabat TUN yang tidak berwenang, dikeluarkan atas dasar penyalahgunaan wewenang dan dikeluarkan atas dasar perbuatan sewenang-wenang.

Pada Undang-Undang Nomor 9 Tahun 2004, dasar atau alasan gugatan terhadap keputusan TUN adalah KTUN bertentangan dengan Peraturan Perundangundangan yang berlaku, sebagaimana pengaturan dalam Undang-Undang Nomor 5 Tahun 1986 dan KTUN bertentangan dengan asasasas umum pemerintahan yang baik. Asas tersebut bukan merupakan sebuah norma yang mudah diukur di dalam pelaksanaannya. Kejelasan akan kewenangan untuk memeriksa jenis sengketa akan mempermudah Hakim yang memeriksa dan mengadili sengketa TUN yang diajukan oleh Penggugat (rakyat). Serta akan memberikan kemudahan bagi rakyat dalam mengukur tindakan pejabat administrasi yang diindikasi merugikan kepentingan rakyat. Hal tersebut sesuai dengan salah satu poin dalam Principles of legality bahwa, "Peraturanperaturan harus disusun dalam rumusan yang bisa dimengerti". Sehingga akan memberikan kejelasan dan mempersempit multiinterpretasi dalam penerapannya.

\section{Juru Sita}

Ada hal baru di dalam Undang-Undang Nomor 9 Tahun 2004, yaitu pengaturan mengenai juru sita dalam Pengadilan TUN, sebagaimana disebutkan pada Pasal 39 A bahwa, "Pada setiap Pengadilan Tata Usaha Negara ditetapkan adanya jurusita". Juru sita pengadilan diangkat oleh Mahkamah Agung dengan syarat sebagai berikut warga negara Indonesia, bertakwa kepada Tuhan Yang Maha Esa, setia kepada Pancasila dan Undang-Undang Dasar Negara Republik Indonesia Tahun 1945, berijazah pendidikan menengah atas (perubahan dengan UndangUndang Nomor 51 Tahun 2009), berpengalaman paling singkat 3 (tiga) tahun sebagai juru sita pengganti dan mampu secara rohani dan jasmani untuk menjalankan tugas dan kewajiban.

Ketentuan mengenai jurusita diatur dalam Pasal 39 A - 39 E Undang-Undang Nomor 9 Tahun 2004. Akan tetapi dalam Undang-Undang tersebut belum disebutkan dengan jelas tugas dan wewenang jurusita dan jurusita pengganti, demikian juga dalam Undang-Undang Nomor 51 Tahun 2009.

6. Pengaturan mengenai pengadilan khusus dan hakim ad hoc

Pada Undang-Undang Nomor 9 Tahun 2004, terdapat ketentuan baru mengenai pengadilan khusus. Dalam Pasal 9 A Undang-Undang Nomor 9 Tahun 2004 disebutkan bahwa, "Di Lingkungan Peradilan Tata Usaha Negara dapat dilakukan pengkhususan yang diatur dengan Undang-Undang. Pengkhususan yang dimaksud pada Pasal $9 \mathrm{~A}$, adalah berupa 
diferensiasi atau spesialisasi di lingkungan Peradilan Tata Usaha Negara, misalnya Pengadilan Pajak. Ketentuan mengenai Pengadilan khusus kembali disempurnakan pada Undang-Undang Nomor 51 Tahun 2009, bahwa pada Pengadilan khusus dapat diangkat hakim ad hoc untuk memeriksa, mengadili dan memutus perkara yang membutuhkan keahlian dan pengalaman dalam bidang tertentu dan dalam jangka waktu tertentu.

7. Transparansi putusan dan pelaksanaan putusan

Dalam Peradilan TUN terdapat satu asas yang diadopsi dari Hukum Administrasi, yaitu asas Prae Sumptio Ius Causa, yaitu suatu Keputusan Tata Usaha Negara (KTUN) dianggap sah sampai ada pembatalan dari Pengadilan. Dengan demikian, pelaksanaan Putusan PTUN menjadi kunci penting dalam suatu sengketa TUN bagi rakyat pencari keadilan. Ketentuan mengenai pelaksanaan putusan diatur di dalam Pasal 116 UndangUndang Nomor 5 Tahun 1986 (dan perubahannya).

Kondisi Hukum di Indonesia yang seringkali tidak mematuhi Putusan Pengadilan Tata Usaha Negara berbeda dengan kondisi Negara lain yang cenderung sudah mapan dalam praktek Negara Hukumnya. Dalam studi perbandingan antara Pengadilan Administrasi di Prancis, Belanda, Belgia dan Luksemburg (Conseil D'Etat), Jerman (Bundesverwaltungsgericht),
Yunani

(Symvoulion

Epikratias), Italia (Consiglio di

Stato), Spanyol (Tribunal

Supremo), Swiss (Tribunal Federal) dan Mahkamah Uni Eropa (European Union Court of Justice), Frank Esparraga mendapatkan salah satu kesimpulan bahwa pelaksanaan Putusan Pengadilan Administrasi di Negara-negara tersebut tidak mengalami kendala yang berarti, disebabkan pada umumnya otoritas publik melaksanakan Putusan Pengadilan "...however, it can be said that in the countries examined, public authorities generally apply the decisions of the courts" (http://www.ptunpalu.go.id/index.php?option $=\mathrm{C}$ om_content\&view=category\&id $=1 \&$ Itemid $=341$ ).

Tidak ditaatinya Putusan Hakim PTUN oleh tergugat, dalam hal ini adalah pejabat Negara, memunculkan lembaga eksekusi baru dalam Undang-Undang Nomor 9 Tahun 2004 maupun UndangUndang Nomor 51 Tahun 2009, yaitu uang paksa dan sanksi administrasi. Selain itu diterapkan pula sanksi berupa pengumuman di media cetak terhadap pejabat yang enggan mematuhi putusan.

Proses pelaksanaan putusan Peradilan TUN, melalui Undang-Undang Nomor 9 Tahun 2004 dan Undang-Undang Nomor 51 Tahun 2009, memperlihatkan dipergunakannya system fixed execution, yaitu eksekusi yang pelaksanaannya dapat dipaksakan oleh Pengadilan melalui sarana-sarana pemaksa yang diatur didalam 


\begin{tabular}{|c|c|}
\hline & $\begin{array}{l}\text { pelaksanaan } \quad \text { Putusan } \\
\text { Pengadilan }\end{array}$ \\
\hline & \multirow{11}{*}{$\begin{array}{l}\text { Thailand. Apabila putusan } \\
\text { Pengadilan menyangkut } \\
\text { kewajiban membayar sejumlah } \\
\text { uang atau penyerahan barang } \\
\text { maka Pengadilan dapa } \\
\text { melakukan eksekusi terhadap } \\
\text { harta kekayaan yang } \\
\text { bersangkutan. Hal tersebut } \\
\text { sesuai dengan Teori Fautes } \\
\text { Personalles, yaitu teori yang } \\
\text { menyatakan bahwa kerugian } \\
\text { terhadap pihak ketiga itu } \\
\text { dibebankan kepada pejabat } \\
\text { yang karena tindakannya } \\
\text { mengakibatkan kerugian }\end{array}$} \\
\hline & \\
\hline & \\
\hline & \\
\hline & \\
\hline & \\
\hline & \\
\hline $\begin{array}{l}\text { Peraturan Perundang- } \\
\text { undangan } \\
\text { (http://ar1fmaulana.blog.uns.ac } \\
\text { id/2011/11/09/perbandingan- } \\
\text { mekanisme-pelaksanaan- } \\
\text { putusan-peradilan- } \\
\text { administrasi-antara-indonesia- } \\
\text { dengan-di-thailand/). } \\
\text { tersebut berbeda dengan } \\
\text { eksekusi putusan Peradilan } \\
\text { TUN yang dilaksanakan pada } \\
\text { Undang-Undang Nomor } 5\end{array}$ & \\
\hline \multirow{3}{*}{$\begin{array}{l}\text { Tahun } 1986 \text { lebih dipengaruhi } \\
\text { oleh asas self respect/self } \\
\text { obicence dan sistem floating } \\
\text { execution, yaitu kewenangan } \\
\text { melaksanakan }\end{array}$} & \\
\hline & \\
\hline & \\
\hline \multirow{3}{*}{$\begin{array}{lcc}\text { Pengadilan yang sudah } & \text { sudat } \\
\text { berkekuatan hukum tetap, } \\
\text { sepenuhnya }\end{array}$} & $\begin{array}{l}\text { (http://www.ptun.palembang.g } \\
\text { o.id/upload_data/penerapan\% } \\
\text { 20upaya\%20hukum\%20paksa. }\end{array}$ \\
\hline & pdf). Sedangkan apabila \\
\hline & Pengadilan \\
\hline $\begin{array}{l}\text { kewenangan bagi Peradilan } \\
\text { TUN untuk menjatuhkan } \\
\text { sanksi. }\end{array}$ & $\begin{array}{l}\text { menyangkut suatu perintah } \\
\text { untuk melakukan atau tidak } \\
\text { melakukan suatu perbuatan, }\end{array}$ \\
\hline $\begin{array}{l}\text { Dalam tataran implementasi } \\
\text { ernyata kedua lembaga } \\
\text { ersebut banyak permasalahan }\end{array}$ & $\begin{array}{l}\text { maka Pengadilan dapa } \\
\text { melakukan eksekusi dengan } \\
\text { menggunakan Hukum Acara }\end{array}$ \\
\hline $\begin{array}{l}\text { Hukum yang mengatur } \\
\text { mengenai prosedur dan } \\
\text { mekanisme cara pembayaran }\end{array}$ & $\begin{array}{l}\text { Perdata secara mutatis } \\
\text { mutandis. } \\
\text { Kejelasan pengaturan } \\
\text { mengenai pelaksaan Putusan }\end{array}$ \\
\hline \multirow{2}{*}{$\begin{array}{l}\text { uang paksa maupun sanksi } \\
\text { administratif, terhadap siapa } \\
\text { uang paksa tersebut }\end{array}$} & Pengadilan \\
\hline & Adminstrasi Thailand tersebut \\
\hline \multirow{2}{*}{$\begin{array}{l}\text { dibebankan, apakah pada } \\
\text { keuangan pribadi pejabat } \\
\text { ataupun keuangan instansi } \\
\text { pejabat Tata Usaha Negara } \\
\text { tersebut dan sanksi } \\
\text { administratif apa yang akan } \\
\text { dijatuhkan kepada tergugat } \\
\text { yang enggan melaksanakan }\end{array}$} & $\begin{array}{l}\text { memberikan jaminan atau } \\
\text { perlindungan Hukum terhadap } \\
\text { para pencari keadilan tersebut, }\end{array}$ \\
\hline & $\begin{array}{l}\text { karena praktis dengan tidak } \\
\text { adanya peraturan mengena } \\
\text { tata cara pelaksanaan upaya } \\
\text { paksa tersebut belum bisa }\end{array}$ \\
\hline \multirow{2}{*}{$\begin{array}{l}\text { putusan } \\
\text { (http://m.hukumonline.com/beri } \\
\text { ta/baca/hol211227). }\end{array}$} & $\begin{array}{lr} & \text { sehingga } \\
\text { pada } & \text { Putusan }\end{array}$ \\
\hline & $\begin{array}{l}\text { Pengadilan TUN yang telah } \\
\text { berkekuatan hukum tetap dan }\end{array}$ \\
\hline \multirow{2}{*}{$\begin{array}{l}\text { Terkait dengan adanya } \\
\text { sanksi pembayaran uang } \\
\text { paksa dan sanksi administrasi, }\end{array}$} & n Pengadilan TUN akan \\
\hline & menjadi \\
\hline
\end{tabular}

\section{Transparansi biaya perkara;}


Pada sistem Peradilan dikenal salah satu asas, yaitu asas peradilan cepat, sederhana dan biaya ringan. Dalam rangka mengcover asas tersebut, dibuatlah pengaturan baru dalam Undang-Undang Nomor 51 Tahun 2009 mengenai transparansi biaya perkara yaitu pada Pasal 144 A - 144 B. Pada Pasal 144 A ayat (1) disebutkan bahwa, "Dalam menjalankan tugas Peradilan, Peradilan Tata Usaha Negara dapat menarik biaya perkara". Biaya perkara meliputi biaya kepaniteraan dan biaya proses penyelesaian perkara. Dalam hal penggugat tidak mampu membayar biaya perkara maka Negara yang menanggungnya,

sebagaimana diatur pada Pasal $144 \mathrm{C}$ ayat (2), "Negara menanggung biaya perkara bagi pencari keadilan yang tidak mampu".

Agar terdapat transparansi, maka penarikan biaya perkara wajib disertai dengan tanda bukti pembayaran yang sah. Bagi pejabat di lingkungan Peradilan TUN dilarang menarik biaya selain biaya kepaniteraan dan biaya proses penyelesaian perkara. Apabila terdapat pejabat yang terbukti melanggar ketentuan tersebut maka dapat dikenai sanksi berupa pemberhentian tidak dengan hormat. Transparansi dalam penyelenggaraan pelayanan publik adalah suatu hal yang penting. Pemberlakuan transparansi dalam penarikan biaya perkara tersebut dilakukan agar penyelenggaraan Peradilan dapat bersih dari KKN.

\section{Bantuan hukum;}

Guna memberikan perlindungan bagi rakyat pencari keadilan yang berperkara di PTUN, maka setiap orang yang berperkara diberikan hak untuk memperoleh bantuan hukum (Pasal $144 \mathrm{C}$ ayat (1) UndangUndang Nomor 51 Tahun 2009). Undang-Undang Nomor 51 Tahun 2009 mengamanahkan pembentukan Pos Bantuan Hukum (POSBAKUM) di setiap Pengadilan Tata Usaha Negara bagi pencari keadilan yang tidak mampu. Bantuan Hukum tersebut diberikan secara cuma-cuma dari tingkatan Pengadilan pertama sampai dengan pelaksanaan putusan.

\section{PENUTUP}

\section{KESIMPULAN}

Indonesia merupakan Negara Hukum, sehingga keberadaan Peradilan Tata Usaha Negara merupakan suatu kebutuhan dalam rangka memberikan perlindungan hakhak asasi warga Negara dari tindakan Pemerintah. Sejarah eksistensi Peradilan Tata Usaha Negara di Indonesia dimulai dengan ditetapkannya Undang-Undang Nomor 5 Tahun 1986 tentang Peradilan Tata Usaha Negara. Seiring dengan perkembangan sistem ketatanegaraan di Indonesia, reasonable apabila dilakukan perubahan terhadap UndangUndang Nomor 5 Tahun 1986. Hal tersebut dilakukan dalam rangka sinkronisasi sistem hukum tentang kekuasaan kehakiman di Indonesia. 
Perubahan-perubahan pokok dalam Undang-Undang Nomor 9 Tahun 2004 tentang Perubahan atas UndangUndang Nomor 5 Tahun 1986 tentang Peradilan dan Undang-Undang Nomor 51 Tahun 2009 tentang Perubahan Kedua atas Undang-Undang Nomor 5 Tahun 1986 tentang Peradilan TUN adalah sebagai berikut dihapuskannya dualisme dalam kekuasaan kehakiman, menjadi satu atap di bawah kekuasaan Mahkamah Agung, diperketatnya persyaratan menjadi Hakim, serta pengaturan yang lebih jelas mengenai pemberhentian Hakim, pengawasan terhadap Hakim di lingkungan Peradilan TUN yang dilakukan secara internal oleh Mahkamah Agung dan pengawasan eksternal oleh Komisi Yudisial, alasan atau dasar pengajuan gugatan, yaitu Keputusan TUN yang bertentangan dengan Peraturan Perundangundangan dan asas-asas umum pemerintahan yang baik, adanya juru sita, adanya Pengadilan khusus dan Hakim ad hoc, transparansi putusan dan adanya upaya paksa (pembayaran uang paksa dan sanksi administrasi) apabila Putusan TUN yang telah memiliki kekuatan Hukum tetap tidak dilaksanakan, transparansi biaya perkara dan adanya Bantuan Hukum bagi rakyat pencari keadilan.

\section{REKOMENDASI/SARAN}

Keberadaan UndangUndang Nomor 9 Tahun 2004 dan Undang-Undang Nomor 51 Tahun 2009 lebih menyempurnakan keberadaan Undang-Undang Nomor 5 Tahun 1986. Walaupun demikian masih terdapat beberapa ketidakjelasan pengaturan khususnya mengenai keberadaan juru sita, dasar gugatan serta pelaksanaan upaya paksa (uang paksa dan sanksi administrasi). Terkait dengan hal tersebut penulis memberikan saran sebagai berikut :

a. Sebaiknya diatur secara lebih terperinci tugas, kewajiban serta wewenang dari juru sita di Pengadilan TUN. Hal tersebut juga terkait dengan peranan juru sita terhadap pelaksanaan upaya administrasi, yaitu berupa pembayaran uang paksa.

b. Terkait dengan dasar atau alasan gugatan di Pengadilan TUN yakni karena adanya Keputusan TUN yang bertentangan dengan Peraturan Perundang-undangan dan asas-asas umum Pemerintahan yang baik. Dasar atau alasan gugatan TUN sebaiknya lebih diperinci dan dirumuskan dalam rumusan yang lebih jelas, sehingga tidak menimbulkan multi-tafsir.

c. Masih adanya kekosongan pengaturan mengenai pelaksanaan upaya paksa, baik pembayaran uang paksa dan sanksi administrasi. Terhadap pembayaran uang paksa, menurut penulis eksekusi dapat dilakukan terhadap harta kekayaan pejabat yang bersangkutan. 


\section{DAFTAR PUSTAKA}

Abdul Latif dan Hasbi Ali, Politik
Hukum, Penerbit Sinar
Grafika, Jakarta, 2011.

Bernard L. Tanya, Politik Hukum Agenda Kepentingan Bersama, Penerbit Genta Publishing, Yogyakarta, 2011.

\begin{tabular}{|c|c|}
\hline Enrico & 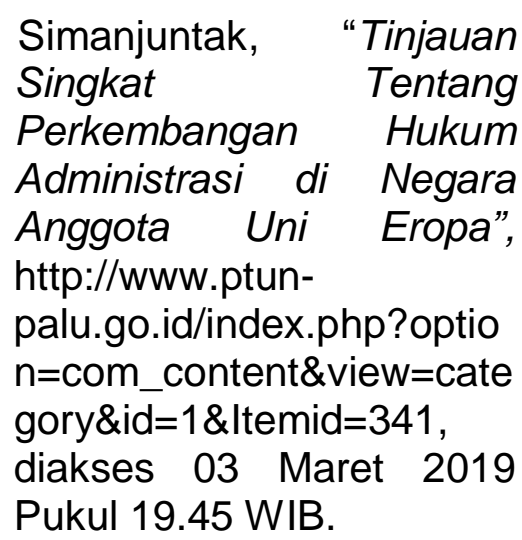 \\
\hline
\end{tabular}

Johnny Ibrahim, Teori dan Metodologi Penelitian Hukum Normatif cetakan kedua, Penerbit Bayumedia Publising, Malang, 2006.

Mirlinda Batalli, "Simplification Of Public Administration Through Use Of Ict And
Other

Tools", http://www.epracticejournal .eu. European Journal of ePractice, diakses tanggal 03 Maret 2019 Pukul 19.38 WIB.

Peter Mahmud Marzuki, Penelitian Hukum, Penerbit Kencana Prenada Media Group, Jakarta, 2010.

R. Otje Salman Soemadiningrat, Rekonseptualisasi Hukum Adat Kontemporer, Penerbit Alumni, Bandung, 2002.

S.F Marbun, Peradilan Administrasi Negara dan Upaya Administrasi di Indonesia, Penerbit FH UII Press, Yogyakarta, 2011.

Susana Rita, "Belum Bertaring Karena Tak Punya Daya Paksa", http://Kompas.com/kompa scetak/061/13/politikhukum/ 2359537.htm, diakses tanggal 03 Maret 2019 Pukul 19.34 WIB.

Tahir Azhary, Negara Hukum, Penerbit Bulan Bintang, Jakarta, 1992.

Ujang Abdullah, "Penerapan Upaya Hukum Paksa Berupa Pembayaran Uang Paksa Di Pengadilan Tata Usaha Negara", http://www.ptun.palemban g.go.id/upload_data/PENE RAPAN\%20UPAYA\%20H UKUM\%20PAKSA.pdf, diakses tanggal 03 Maret 2019 Pukul 19.30 WIB. 


Undang-Undang Nomor 48 Tahun
2009 sebagai bentuk
penyempurnaan Undang-
Undang Nomor 4 Tahun
2004 tentang Kekuasaan
Kehakiman.

